\title{
PERANAN AERASI SEL ELEKTROLISIS DALAM PEMBENTUKAN PORI PADA PROSES ANODIZING LOGAM ALUMINIUM
}

\author{
Eko Budiyanto1', Lukito Dwi Yuono² \\ Jurusan Teknik Mesin, Universitas Muhammadiyah Metro \\ Jl. Ki Hajar Dewantara No. 116 Metro, Lampung, Indonesia \\ Email: eko_budiyanto99@yahoo.com¹, lukitodwiyuono@gmail.com²
}

\begin{abstract}
Abstrak
Penelitian ini bertujuan untuk mengetahui peranan aerasi sel elektrolisis dalam pembentukan pori pada lapisan proses anodizing logam Aluminium. Selain Beda potensial, Pembentukan lapisan oksida pada permukaan Aluminium juga dipengaruhi oleh jumlah oksigen yang terdapat pada larutan elektrolit. Pengaliran udara (aerasi) pada proses ini diharapkan akan menyuplai sejumlah oksigen pada sel elektrolisis sehingga larutan elektrolit tidak mengalami defisit oksigen. Tujuan lain penambahan aliran udara pada proses ini adalah untuk menciptakan rongga pori pada oksida Aluminium yang dibentuk. Kualitas produk hasil anodizing ditentukan oleh ketebalan pori yang terbentuk serta jarak antar pori. Untuk keperluan yang membutuhkan material bersifat dekoratif, jarak antar pori yang terbentuk haruslah saling berdekatan untuk menghindari pewarnaan yang kurang merata. Material yang digunakan dalam penelitian ini adalah Aluminium paduan Mangan dan Silikon (Al-Mg-Si). Ukuran spesimen anodizing Aluminium adalah 60 x $15 \times 3(\mathrm{~mm})$. Tahap preparasi Aluminium dilakukan pembersihan secara fisik dan kimiawi, spesimen dicuci menggunakan alkohol dan aquadest yang selanjutnya dilakukan perendaman pada larutan Natrium Hidroksida $(\mathrm{NaOH})$ selama 2 menit. Proses anodizing Aluminium menggunakan asam sulfat $\left(\mathrm{H}_{2} \mathrm{SO}_{4}\right)$ sebagai elektrolit dengan beda potensial $25 \mathrm{~V}$ selama 3 menit dan variasi aerasi 5, 10, dan $15 \mathrm{lpm}$. Jarak antar sel elektrolisis diatur sejauh $20 \mathrm{~cm}$. Hasil dari proses anodizing, material diuji dan dianalisa karakteristik permukaannya menggunakan uji Scanning Electron Microscopy (SEM). Hasil yang diperoleh adalah debit aerasi pada proses anodizing memberikan pengaruh yang signifikan terhadap nilai degradasi material Aluminium. Pada debit aerasi masingmasing $10 \mathrm{lpm}, 15 \mathrm{lpm}$, dan $20 \mathrm{lpm}$ diperoleh nilai degradasi sebesar 0.0009 gr $(0.0123 \%)$, 0.0095 gr $(0.1319 \%), 0.041$ gr $(0.5621 \%)$. Sedangkan karakteristik permukaan, bentuk, dan jarak antar pori dapat dipresentasikan dalam gambar hasil pengamatan SEM.
\end{abstract}

Kata Kunci : Aluminium, anodizing, aerasi, SEM, pori.

\section{PENDAHULUAN}

Aluminium merupakan salah satu logam non-ferrous yang paling banyak dipergunakan dalam bidang keteknikan karena memiliki sifat yang ringan, tahan terhadap korosi, dan dapat didaur ulang [1]. Aluminium sering dimanfaatkan sebagai bahan baku pembuatan berbagai perlengkapan rumah tangga, industri otomotif, hingga pembuatan pesawat terbang. Hal ini dikarenakan Aluminium memiliki beberapa sifat yang unggul seperti kuat, ringan, serta konduktivitas panas dan listrik tinggi. Aluminium juga memiliki sifat mampu mesin (machinabillity) dan sifat mampu cor (castabllity) baik, serta mudah ditempa (formability) dan lain-lain [2]. Selain karena keistimewaan dari sifat fisis yang dimiliki oleh logam Aluminium, kebutuhan pasar dunia terhadap logam Aluminium juga berhubungan dengan segi estetika. Berbagai industri seperti industri peralatan komunikasi (handphone), industri otomotif, dan industri peralatan rumah tangga adalah industri yang sudah menggunakan teknik pewarnaan logam Aluminium untuk meningkatkan nilai estetika logam tersebut. 
Teknik pewarnaan logam Aluminium yang digunakan dalam industri adalah teknik pelapisan logam Aluminium dengan menggunakan pewarna (dye) ataupun dengan Chrome (Cr). Penggunaan teknik pelapisan dengan menggunakan pewarna maupun Chrome mempunyai beberapa kelemahan, yaitu mudah terkelupasnya pewarna ataupun Chrome pelapis logam Aluminium. Kelemahan ini akan berdampak pada daya beli pasar terhadap peralatan yang berbahan dasar Aluminium. Untuk meningkatkan nilai estetika pada logam Aluminium sebagai bahan dasar dalam sebuah industri, maka salah satu cara yang dapat digunakan adalah dengan memadukan antara logam Aluminium dengan logam lain yang memiliki nilai estetika lebih tinggi seperti emas atau tembaga. Teknik yang paling tepat digunakan untuk logam Aluminium yaitu teknik anodizing [3].

Teknik anodizing adalah suatu proses penyepuhan logam yang didasarkan atas pembentukan lapisan oksida Aluminium melalui oksidasi yang terkontrol sehingga terbentuk pori, pori inilah yang kemudian dilapisi/diisi oleh lapisan logam lain. Secara umum teknik anodizing dapat dibedakan menjadi dua jenis yaitu, regular anodizing dan hard anodizing. Yang membedakan dari kedua jenis teknik tersebut adalah atas dasar kuat atau lemahnya proses pembentukan oksida logam melalui pengontrolan. Teknik regular anodizing digunakan untuk keperluan yang bersifat dekoratif, sedangkan teknik hard anodizing lebih bertujuan meningkatkan kekuatan fisik dari sebuah logam. Teknik anodizing dapat digunakan untuk meningkatkan ketahanan logam Aluminium terhadap korosi serta meningkatkan ketahanan fisik serta keausan logam Aluminium. Pemilihan teknik anodizing akan sangat bergantung pada keperluan. Jika yang diperlukan hanya sebatas membuat Aluminium yang dekoratif atau memiliki nilai estetika maka cukup digunakan anodizing jenis regular anodizing [4].
Teknik anodizing pada dasarnya menggunakan prinsip elktrolisis. Berdasarkan jenis elektrolit yang digunakan, teknik yang paling umum digunakan dalam anodizing adalah jenis sulfuric acid anodizing. Hal ini disebabkan teknik ini yang paling bernilai ekonomis. Konsentrasi asam sulfat yang paling optimum digunakan untuk teknik anodizing adalah 15\%. Pada konsentrasi 15\%, karakteristik permukaan logam Aluminium hasil anodizing memberikan tingkat kekerasan dan keausan yang paling optimal [5]. Hal lain yang mempengaruhi kualitas Aluminium hasil anodizing adalah besar beda potensial yang diberikan. Perbedaan besar beda potensial yang diberikan akan mempengaruhi lebar dan ketebalan pori oksida Aluminium yang terbentuk [6].

Kualitas produk hasil anodizing ditentukan oleh ketebalan pori yang terbentuk serta jarak antar pori. Jarak antar pori yang terbentuk haruslah saling berdekatan untuk menghindari pewarnaan yang kurang merata [4]. Berdasarkan data SNI No.07-0734-1989 tentang kualitas lapisan anodisasi Aluminium, ketebalan pori oksida yang terbaik adalah pada kisaran $\pm 18 \mu$ m untuk keperluan dekoratif. Untuk keperluan khusus seperti peningkatan kekuatan fisik logam, SNI mempersyaratkan ketebalan pori rata-rata diatas $20 \mu \mathrm{m}$. Keperluan khusus lebih cenderung pada kebutuhan konsumen terhadap kekuatan fisik dan keausan logam Aluminium hasil anodizing.

Pada proses anodizing, logam Aluminium yang telah dipreparasi dihubungkan dengan kutub positif power supply sedangkan kutub negatifnya akan dihubungkan dengan logam Aluminium lain. Kemudian pada sel ini dialirkan beda potensial. Beda potensial ini akan memicu pertumbuhan lapisan oksida pada permukaan logam Aluminium. Selain Beda potensial, Pembentukan lapisan oksida pada permukaan Aluminium juga dipengaruhi oleh jumlah oksigen yang terdapat pada larutan elektrolit. Pengaliran udara (aerasi) pada proses ini diharapkan 
akan menyuplai sejumlah oksigen pada sel elektrolisis sehingga larutan elektrolit tidak mengalami defisit oksigen. Tujuan lain penambahan aliran udara pada proses ini adalah untuk menciptakan rongga pori pada oksida Aluminium yang dibentuk. Terbentuknya pori pada oksida menandakan proses anodizing berhasil dilakukan [4].

Dikarenakan pentingnya aerasi sel elektrolisis dalam proses anodizing, maka perlu dilakukan penelitian untuk mengetahui seberapa berpengaruhnya aerasi terhadap ukuran pori yang dihasilkan dalam proses anodizing. Dengan memvariasikan debit aerasi, maka akan diketahui debit aerasi yang tepat untuk pembentukan pori yang sesuai dengan kebutuhan. Sehingga dapat dinterprestasikan peranan aerasi dalam pembentukan pori pada proses anodizing logam Aluminium.

\section{TINJAUAN PUSTAKA}

Anodizing merupakan proses elektrolit dengan logam dijadikan anoda dalam elektrolit sesuai, sehingga bila dialiri listrik, permukaan logamnya diubah menjadi oksidanya, serta mempunyai sifat dekoratif, protektif, dan manfaat lainnya. Sesuai dengan sifat dan kerja elektrolit terhadap oksida anodik, kondisi operasi, juga hubungan tegangan/arus, anoda logam terus terdegradasi dan diubah menjadi oksida yang terus bereaksi ke bagian dalam. Oksida yang terbentuk terakhir berdekatan dengan antar muka logam pelapis.

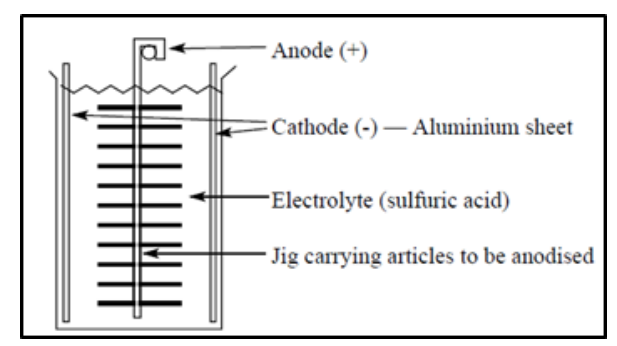

Gambar 1. Skema anodizing

Aluminium adalah logam putih yang liat dan dapat ditempa; bubuknya berwarna abu-abu. Logam ini melebur pada $659^{\circ} \mathrm{C}$. Bila terkena udara, objek-objek aluminium teroksidasi pada permukaannya, tetapi lapisan oksida ini melindungi objek dari oksida lebih lanjut.

Untuk menaikkan ketahanan terhadap korosi, logam aluminium dianodasi artinya produk logam aluminium sengaja dilapisi dengan aluminium oksida secara elektrolisis. Aluminium yang dianodasi ini mempunyai ketebalan lapisan 0,01 $\mathrm{mm}$ dan lapisan oksida setebal ini mampu menyerap warna/zat warna sehingga permukaan logam dapat diwarnai. Pada proses "anodasi" ini, logam aluminium dipasang sebagai anode, karbon/grafit sebagai katode dan dipakai elektrolit larutan asam sulfat. Persamaan reaksi elektrolisisnya yaitu :

Pada anode terjadi oksidasi $\mathrm{Al}$ :

$2 \mathrm{Al}(\mathrm{s})+6 \mathrm{H}_{2} \mathrm{O}(\mathrm{l}) \rightarrow \mathrm{Al}_{2} \mathrm{O}_{3}(\mathrm{~s})+6 \mathrm{H}_{3} \mathrm{O}+$ (aq) +6 e (reaksi ini tidak akan berlanjut ketika anode $\mathrm{Al}$ telah terlapisi rata oleh $\mathrm{Al}_{2} \mathrm{O}_{3}$ )

Pada katode (reduksi) :

$6 \mathrm{H}_{3} \mathrm{O}+(\mathrm{aq})+6 \mathrm{e} \rightarrow 6 \mathrm{H}_{2} \mathrm{O}(\mathrm{l})+\mathrm{H}_{2}(\mathrm{~g})$

Logam aluminium yang dilapisi dengan oksida dapat mencegah pengkaratan. Ketahanan maksimum terhadap pengkaratan berada pada selang pH 4,5 sampai 8,5. Kebanyakan aluminium yg digunakan secara komersial diberi perlakuan sedemikian rupa agar dapat terlapis dengan oksida. Salah satu metode yang dinamakan anodizing dilakukan dengan cara objek aluminium dibuat sebagai anoda dan batang grafit dibuat sebagai katode dengan larutan elektrolit berupa asam sulfat $\left(\mathrm{H}_{2} \mathrm{SO}_{4}\right)$.

Pada saat elektrolisis, peristiwa yang terjadi di elektroda ialah reaksi redoks. Di katoda (kutub negatif), reaksi reduksi dapat berupa pengendapan logam atau timbulnya gas $\mathrm{H}_{2}$. Di anoda (kutub positif), oksidasi dapat berupa pelarutan logam atau timbulnya gas $\mathrm{O}_{2}$.

Proses penganodaan aluminium adalah proses elektrolisa sebagai elektrolit adalah asam sulfat. Benda dari logam aluminium dipasang pada kutub positif dan mengalami reaksi oksidasi pada permukaannya. Dengan demikian 
terbentuklah suatu lapisan oksida aluminium pada permukaan benda itu, sehingga akan merupakan lapisan pelindung yang sekaligus dapat berfungsi dekoratif. Dalam pengamatan yang lebih dalam, oksida yang terbentuk membentuk lapisan berpori seperti yang ditujnjukkan pada Gambar 2.

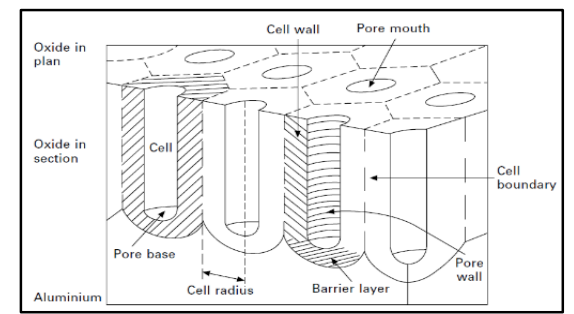

Gambar 2. Skema penjabaran lapisan anodik berpori pada aluminium [3].

Pada prinsipnya, ketika arus dialirkan pada suatu larutan garam, ion logam akan berpindah pada katoda dan ion dari radikal asam akan berpindah pada anoda. Pertukaran kimia ini terjadi pada permukaan kedua buah elektroda. Pada katoda akan terjadi reduksi dan pada anoda akan terjadi oksidasi.

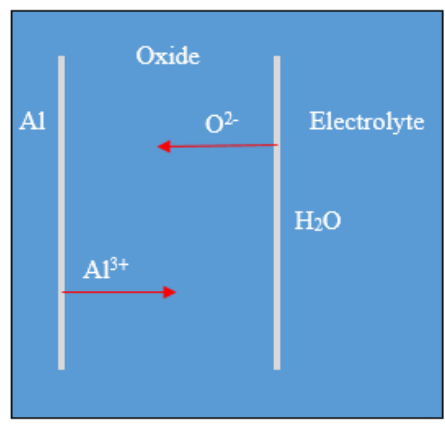

Gambar 3. Transfer ion pada proses Anodizing Aluminium

Hasil utama pada katoda adalah endapan logam, tetapi pada beberapa kasus juga terjadi reduksi ion hidrogen membentuk gas hidrogen sebagai produk samping. Jika anoda merupakan logam yang sama dengan logam yang akan diendapkan pada katoda, maka anoda akan dioksidasi dan dilarutkan. Pengaruh arus dan beda potensial terhadap pertumbuhan lapisan oksida berpori ditunjukkan pada Gambar 4.

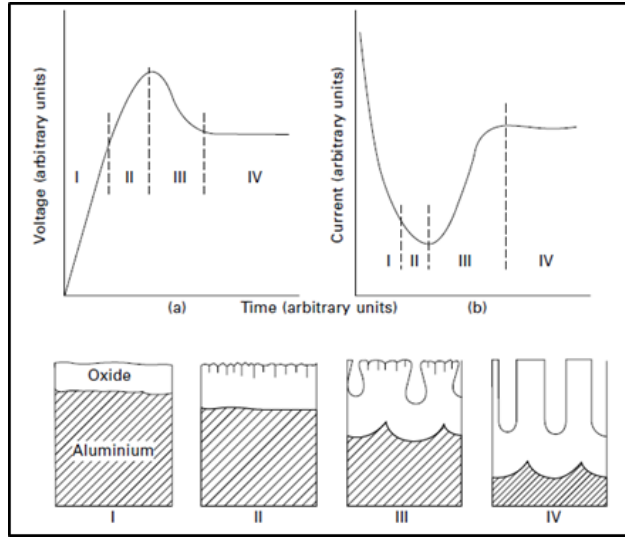

Gambar 4. Diagram pertumbuhan lapisan anodik berpori pada Aluminium, (a)

kondisi Arus konstan, (b) kondisi beda potensial konstan [3].

\section{METODE PENELITIAN}

\section{Variabel Penelitian}

Variabel yang digunakan dalam penelitian ini adalah sebagai berikut:

1. Variabel Bebas. Variabel bebas adalah variabel yang besarannya ditentukan sebelum dilakukan dan tidak dipengaruhi variabel lain. Pada penelitian ini variabel bebasnya adalah debit aerasi (10 lpm, $15 \mathrm{lpm}$, dan 20 lpm),

2. Variabel Terikat. Variabel terikat adalah variabel yang besar nilainya tergantung pada variabel bebas dan nilainya diperoleh setelah pelaksanaan penelitian. Pada penelitian ini variabel terikatnya adalah karakteristik permukaan logam aluminium (jarak dan diameter pori) Aluminium hasil anodizing,

3. Variabel Terkontrol. Variabel terkontrol adalah variabel yang besarannya dikendalikan atau dibuat tetap selama penelitian. Pada penelitian ini variabel terkontrolnya adalah konsentrasi elektrolit, beda potensial, jarak anoda-katoda, dan suhu ruang.

\section{Waktu dan Tempat Penelitian}

Penelitian ini dilakukan pada bulan April sampai November 2018, di Laboratorium Teknik Mesin Kampus II 
Universitas Muhammadiyah Metro, Lampung.

\section{Alat dan Bahan Penelitian}

Peralatan

1. Kompresor udara $1 \mathrm{HP}$,

2. Bak kaca ukuran $25 \times 10 \times 10(\mathrm{~cm})$,

3. Flowmeter,

4. Adaptor,

5. Timbangan digital,

6. Mistar baja,

7. Ampere meter,

8. Gelas ukur,

9. Vernier caliper,

10. Sikat kawat,

11. Wadah acrillyc,

12. Kabel,

13. Penjepit kabel (conector),

14. Camera digital,

15. SEM (Scanning Electron Microscope),

16. Air valve (kran udara),

17. Selang kompresor,

18. Gerinda,

19. Mata gerinda potong,

20. Stopwatch,

21. Alat uji komposisi material,

22. Voltmeter.

Bahan

1. Plat Aluminium dengan ketebalan 3 $\mathrm{mm}$,

2. Larutan Asam Sulfat $15 \%$,

3. Sabun,

4. Aquades,

5. Larutan $\mathrm{NaOH}$,

Bentuk dan dimensi spesimen anodizing ditunjukkan pada Gambar 5.

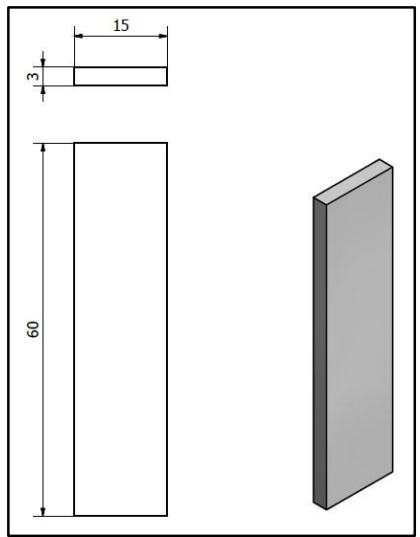

Gambar 5. Spesimen anodizing
Prosedur Penelitian

Penelitian ini dilakukan dalam 5 tahapan yaitu preparasi larutan $\mathrm{NaOH} 1 \mathrm{M}$, preparasi larutan asam sulfat, preparasi logam Aluminium, tahap anodizing logam Aluminium, dan uji karakteristik (pengamatan) logam Aluminium hasil anodizing dengan SEM.

Preparasi Larutan $\mathrm{NaOH} 1 \mathrm{M}$

1. 10 gram padatan $\mathrm{NaOH}$ dimasukkan ke dalam gelas ukur,

2. Kemudian $\mathrm{NaOH}$ dilarutkan dengan $250 \mathrm{ml}$ aquadest.

Preparasi Larutan Asam Sulfat

1. Larutan asam sulfat $15 \%$ disiapkan dengan cara mengencerkan asam sulfat dengan aquadest,

2. Tuang $78,11 \mathrm{ml}$ asam sulfat pekat $96 \%$ ke dalam gelas ukur,

3. Larutkan asam sulfat dengan aquadest hingga volumenya menjadi $500 \mathrm{ml}$.

Preparasi Logam Aluminium

1. Pelat logam Aluminium dengan ketebalan $3 \mathrm{~mm}$ dipotong dengan ukuran $60 \times 15 \mathrm{~mm}$ menjadi 18 spesimen untuk 9 kali percobaan, 9 spesimen sebagai anoda dan 9 spesimen lainnya sebagai katoda,

2. Spesimen kemudian dibersihkan secara fisik dari kotoran yang menempel dengan menggunakan alkohol,

3. Setelah dibersihkan dengan alkohol, spesimen dibersihkan dengan sabun dan aquadest,

4. Tahap pembersihan secara fisik dilanjutkan dengan pembersihan secara kimiawi, logam Aluminium direndam dalam larutan $\mathrm{NaOH} 1 \mathrm{M}$ dalam suhu ruangan selama 2 menit untuk menghilangkan kotoran yang lolos dari pembersihan secara fisik (proses degreasing),

5. Setelah melalui proses degreasing, pelat Aluminium kembali dibersihkan dengan menggunakan aquadest. 
Tahap Anodizing Logam Aluminium

1. Logam aluminium yang telah dibersihkan kemudian di-anodizing,

2. Logam aluminium yang akan dianodizing dihubungkaan dengan kutub positif power supply (Aluminium bertindak sebagai anoda),

3. Kemudian kutub negatif power supply dihubungkan pada logam aluminium lainnya (katoda),

4. Kedua elektroda ini kemudian dicelupkan kedalam larutan asam sulfat dengan konsentrasi $15 \%$ yang kemudian dialirkan listrik dengan beda potensial $25 \mathrm{~V}$ (Kusuma, Karyasa, \& Suardana, 2014),

5. 3 pasang spesimen untuk anodizing yang diberikan aliran udara dengan debit aliran 5 lpm pada sel elektrolisis,

6. 3 pasang spesimen untuk anodizing yang diberikan aliran udara dengan debit aliran $10 \mathrm{lpm}$ pada sel elektrolisis,

7. 3 pasang spesimen untuk anodizing yang diberikan aliran udara dengan debit aliran $15 \mathrm{lpm}$ pada sel elektrolisis,

8. Anodizing dilakukan selama 10 menit pada suhu ruang,

9. Jarak antar elektroda diatur sejauh $20 \mathrm{~cm}$,

10. Pengaliran udara menggunakan kompresor yang ditambahkan air valve sebagai pengatur debit aliran udara dan flowmeter pada selang kompresor,

11. Skema anodizing dapat dilihat pada Gambar 6.

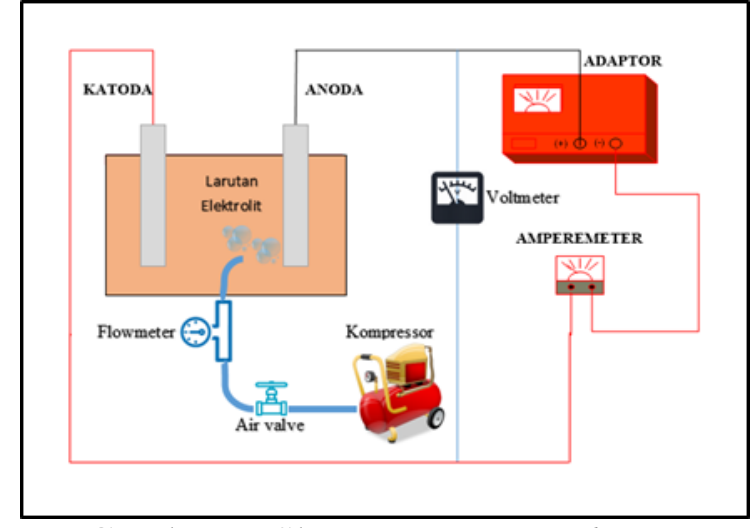

Gambar 6. Skema proses anodizing Aluminium

Uji Karakteristik permukaan Logam Aluminium Hasil Anodizing dengan SEM

1. Setelah spesimen melalui prose anodizing, spesimen dilakukan uji karakteristik permukaan logam Aluminium,

2. Sebelum dilakukan uji karakteristik permukaan logam Aluminium, spesimen dipreparasi dengan menggunakan uv-bath,

3. Kemudian spesimen diukur konduktivitas listriknya untuk mempermudah pengoperasian serta pembacaan data SEM,

4. Spesimen dilakukan uji karakteristik permukaan logam Aluminium menggunakan SEM,

5. Pengamatan Uji karakteristik permukaan logam menggunakan SEM akan memberikan hasil berupa ketebalan dan lebar pori rata-rata pada permukaan lapisan oksida aluminium serta hasil berupa gambaran sebaran pori yang terbentuk selama proses anodizing berlangsung,

6. Hasil uji karakteristik permukaan logam Aluminium dianalisa.

\section{HASIL DAN PEMBAHASAN}

\section{Komposisi Kimia Aluminium}

Hasil pengujian komposisi kimia menggunakan mesin uji OES (Optical Emission Spectroscopy) yang dilakukan di Laboratorium Lembaga Ilmu Pengetahuan 
Indonesia (LIPI) Tanjung Bintang dapat dilihat pada Tabel 1.

Tabel 1. Komposisi kimia material Aluminium

\begin{tabular}{|c|c|c|c|c|c|c|c|c|c|}
\hline $\begin{array}{c}\text { Unsu } \\
\mathrm{r}\end{array}$ & $\mathrm{Si}$ & $\begin{array}{c}\mathrm{C} \\
\mathrm{u}\end{array}$ & $\begin{array}{c}\mathrm{M} \\
\mathrm{g}\end{array}$ & $\mathrm{Fe}$ & $\mathrm{Cr}$ & $\begin{array}{c}\mathrm{Z} \\
\mathrm{n}\end{array}$ & $\mathrm{Ti}$ & $\begin{array}{c}\mathrm{S} \\
\mathrm{n}\end{array}$ & $\mathrm{Al}$ \\
\hline $\begin{array}{c}\text { Spesi } \\
\text { men }\end{array}$ & 0. & 0. & 0. & 0. & 0. & 0. & 0. & 0. & $\begin{array}{c}\text { Bala } \\
\text { nce }\end{array}$ \\
\hline
\end{tabular}

Berdasarkan hasil pengujian komposisi kimia tersebut di atas, maka material Aluminium digolongkan ke dalam material Aluminium dengan paduan Mangan dan Silikon (Al-Mg-Si) dengan seri Al 6061 [7].

\section{Persen Degradasi Aluminium Hasil Anodizing}

Setelah melalui proses anodizing dengan variasi debit aerasi, material aluminium mengalami pengurangan volume maupun berat/massa. Untuk menentukan nilai persentase pengurangannya, maka perlu dilakukan 2 kali penimbangan pada setiap spesimen yakni sebelum dan sesudah proses anodizing. Hasil pengukuran berat sebelum proses anodizing disimbolkan dengan kode g1. Hasil pengukuran berat sesudah proses anodizing disimbolkan dengan kode g2. Spesimen yang diuji berjumlah 9 spesimen. 3 spesimen dilakukan proses anodizing dengan debit aerasi 10 liter per menit (lpm), 3 spesimen berikutnya dilakukan proses anodizing dengan debit aerasi $15 \mathrm{lpm}$, dan 3 spesimen yang lain dilakukan proses anodizing dengan debit aerasi $20 \mathrm{lpm}$. Semua pengujian menggunakan beda potensial $25 \mathrm{~V}$ dan jarak antara anoda dan katoda adalah $20 \mathrm{~cm}$. Data hasil pengukuran berat sebelum dan sesudah proses anodizing Aluminium dapat dilihat pada Tabel 2.
Tabel 2. Data hasil pengukuran berat material

\begin{tabular}{|c|c|c|c|c|c|}
\hline $\begin{array}{c}\text { Spes } \\
\text { imen }\end{array}$ & $\begin{array}{c}\text { Jarak } \\
\text { Anoda- } \\
\text { Katoda } \\
(\mathrm{cm})\end{array}$ & $\begin{array}{c}\text { Beda } \\
\text { Poten } \\
\text { sial } \\
(\mathrm{V})\end{array}$ & $\begin{array}{c}\text { Debit } \\
\text { Aerasi } \\
(\mathrm{lpm})\end{array}$ & $\begin{array}{c}\mathrm{g} 1 \\
(\mathrm{gr})\end{array}$ & $\begin{array}{c}\mathrm{g} 2 \\
(\mathrm{gr})\end{array}$ \\
\hline 1 & 20 & 25 & 10 & 7.2917 & 7.2910 \\
\hline 2 & 20 & 25 & 10 & 7.2883 & 7.2873 \\
\hline 3 & 20 & 25 & 10 & 7.3002 & 7.2994 \\
\hline 4 & 20 & 25 & 15 & 7.2235 & 7.2145 \\
\hline 5 & 20 & 25 & 15 & 7.1118 & 7.1024 \\
\hline 6 & 20 & 25 & 15 & 7.2668 & 7.2568 \\
\hline 7 & 20 & 25 & 20 & 7.3101 & 7.2723 \\
\hline 8 & 20 & 25 & 20 & 7.2907 & 7.2465 \\
\hline 9 & 20 & 25 & 20 & 7.2798 & 7.2388 \\
\hline
\end{tabular}

Dari hasil pengukuran yang ditunjukkan pada Tabel 2 kemudian dihitung nilai pengurangan berat dari masing-masing spesimen dengan 3 variasi debit aerasi dan diambil nilai rata-ratanya. Nilai pengurangan berat spesimen setelah proses anodizing ditunjukkan oleh Tabel 3.

Tabel 3. Nilai pengurangan berat spesimen karena proses anodizing

\begin{tabular}{|c|c|c|c|c|}
\hline Spesimen & $\begin{array}{c}\text { Debit } \\
\text { Aerasi } \\
(\mathrm{lpm})\end{array}$ & $\begin{array}{c}\mathrm{g} 1 \\
(\mathrm{gr})\end{array}$ & $\begin{array}{c}\mathrm{g} 2 \\
(\mathrm{gr})\end{array}$ & $\begin{array}{c}\mathrm{g} 1-\mathrm{g} 2 \\
(\mathrm{gr})\end{array}$ \\
\hline 1 & 10 & 7.2917 & 7.2910 & 0.0007 \\
\hline 2 & 10 & 7.2883 & 7.2873 & 0.001 \\
\hline 3 & 10 & 7.3002 & 7.2994 & 0.0008 \\
\hline Rata-rata & & 7.2934 & 7.2925 & 0.0009 \\
\hline 4 & 15 & 7.2235 & 7.2145 & 0.009 \\
\hline 5 & 15 & 7.1118 & 7.1024 & 0.0094 \\
\hline 6 & 15 & 7.2668 & 7.2568 & 0.01 \\
\hline Rata-rata & & 7.2007 & 7.1912 & 0.0095 \\
\hline 7 & 20 & 7.3101 & 7.2723 & 0.0378 \\
\hline 8 & 20 & 7.2907 & 7.2465 & 0.0442 \\
\hline 9 & 20 & 7.2798 & 7.2388 & 0.041 \\
\hline Rata-rata & & 7.2935 & 7.2525 & 0.041 \\
\hline
\end{tabular}

Dari Tabel 3 dapat diketahui bahwa nilai kehilangan berat (degradasi) yang terjadi sangat dipengaruhi oleh nilai debit aerasi. Pada debit aerasi $10 \mathrm{lpm}$, nilai kehilangan berat material hasil anodizing sebanyak 0.00083 gram, pada debit aerasi $15 \mathrm{lpm}$, nilai kehilangan berat material hasil anodizing sebanyak 0.0095 gram, Pada debit aerasi $20 \mathrm{lpm}$, nilai kehilangan berat material hasil anodizing sebanyak 0.041 gram. Nilai degradasinya meningkat seiring besarnya debit aerasi yang diberikan. Untuk menghitung persen degradasi pada material 
Aluminium hasil anodizing dapat dihitung menggunakan rumus:

$$
\% \text { Degradasi }=\frac{\mathrm{g} 1-\mathrm{g} 2}{\mathrm{~g} 1} \cdot 100 \%
$$

Dengan g1 adalah berat spesimen sebelum proses anodizing, g2 adalah berat spesimen setelah proses anodizing. Persen degradasi untuk spesimen yang dilakukan proses anodizing dengan debit aerasi 10 lpm dihitung dengan:

$$
\begin{aligned}
\% \text { Degradasi }(10 \mathrm{lpm}) & =\frac{\mathrm{g} 1-\mathrm{g} 2}{\mathrm{~g} 1} \cdot 100 \% \\
& =\frac{0.0009}{7.2934} \cdot 100 \% \\
& =0.0123 \%
\end{aligned}
$$

Dari perhitungan tersebut diperoleh nilai degradasi pada spesimen Aluminium yang telah dilakukan proses anodizing dengan debit aerasi $10 \mathrm{lpm}$ sebesar 0.0123 $\%$. Persen degradasi untuk spesimen yang dilakukan proses anodizing dengan debit aerasi 15 lpm dihitung dengan:

$$
\begin{aligned}
\% \text { Degradasi }(15 \mathrm{lpm}) & =\frac{\mathrm{g} 1-\mathrm{g} 2}{\mathrm{~g} 1} \cdot 100 \% \\
& =\frac{0.0095}{7.2007} \cdot 100 \% \\
& =0.1319 \%
\end{aligned}
$$

Dari perhitungan tersebut diperoleh nilai degradasi pada spesimen Aluminium yang telah dilakukan proses anodizing dengan debit aerasi $15 \mathrm{lpm}$ sebesar 0.1319 $\%$. Persen degradasi untuk spesimen yang dilakukan proses anodizing dengan debit aerasi 20 lpm dihitung dengan:

$$
\begin{aligned}
\% \text { Degradasi }(20 \mathrm{lpm}) & =\frac{\mathrm{g} 1-\mathrm{g} 2}{\mathrm{~g} 1} \cdot 100 \% \\
& =\frac{0.041}{7.2935} \cdot 100 \% \\
& =0.5621 \%
\end{aligned}
$$

Dari perhitungan tersebut diperoleh nilai degradasi pada spesimen Aluminium yang telah dilakukan proses anodizing dengan debit aerasi 20 lpm sebesar 0. 5621 $\%$. Kenaikan nilai persen degradasi material hasil anodizing dapat dipresentasikan melalui Gambar 7.

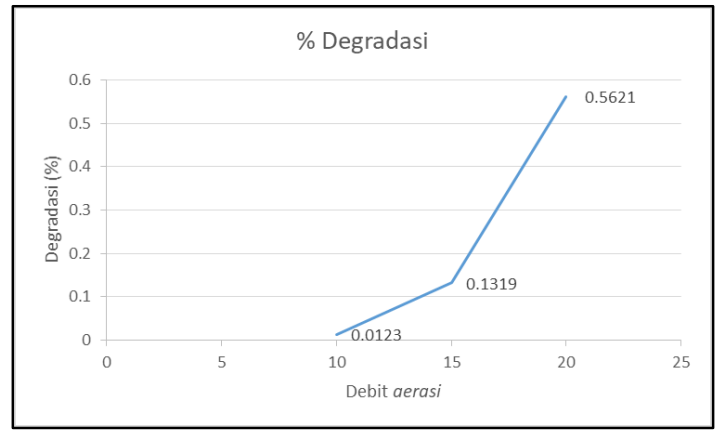

Gambar 7. Persen degradasi Aluminium karena faktor debit aerasi pada proses anodizing

\section{Karakteristik Permukaan Logam Aluminium}

Pengamatan SEM hasil anodizing ditunjukkan pada Gambar 8.

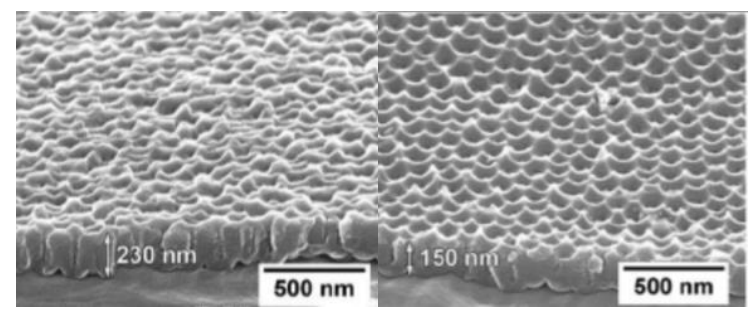

(a)

(b)

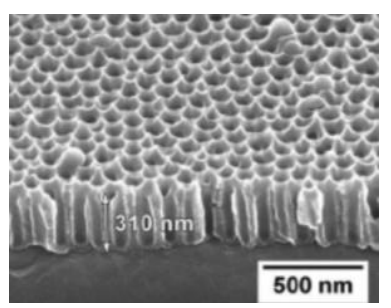

(c)

Gambar 8. Lapisan pori permukaan aluminium hasil anodizing menggunakan debit aerasi (a) 10 lpm, (b) 15 lpm, (c) 20 lpm.

Proses anodizing menggunakan debit aerasi $10 \mathrm{lpm}$ memberikan hasil lapisan oksidasi dengan ketinggian pori pada permukaan aluminium sebesar 230 $\mathrm{nm}$, Proses anodizing menggunakan debit aerasi $15 \mathrm{lpm}$ memberikan hasil lapisan oksidasi dengan ketinggian pori pada permukaan aluminium sebesar $150 \mathrm{~nm}$, dan proses anodizing menggunakan debit aerasi 10 lpm memberikan hasil lapisan oksidasi dengan ketinggian pori pada permukaan aluminium sebesar $310 \mathrm{~nm}$. Sedangkan jarak antar pori atau biasa disebut dengan kerapatan pori menunjukkan bahwa pada 
proses anodizing dengan debit aerasi 10 lpm cenderung lebih lebar, sehingga untuk keperluan material aluminium sebagai material dengan sifat dekoratif maka proses anodizing menggunakan debit aerasi 15 lpm dan $20 \mathrm{lpm}$ adalah yang lebih direkomendasikan.

\section{KESIMPULAN}

Dari hasil pengujian, pengamatan, dan perhitungan dapat disimpulkan sementara yaitu:

1. Debit aerasi pada proses anodizing memberikan pengaruh yang signifikan terhadap nilai degradasi material Aluminium,

2. Semakin besar debit aerasi menyebabkan semakin besar nilai degradasi material Aluminium yang dilakukan proses anodizing .

3. Untuk keperluan material aluminium sebagai material dengan sifat dekoratif maka proses anodizing menggunakan debit aerasi $15 \mathrm{lpm}$ dan $20 \mathrm{lpm}$ adalah yang lebih direkomendasikan.

\section{REFERENSI}

[1]. Budiyanto, E., Nugroho, E., \& Zainudin, A. (2018). UJI KETAHANAN FATIK ALUMINIUM SCRAP HASIL REMELTING PISTON BEKAS MENGGUNAKAN ALAT UJI FATIK TIPE ROTARY BENDING. Turbo: Jurnal Program Studi Teknik Mesin, 7(1).

[2]. Nugroho, F. (2015). PENGARUH RAPAT ARUS ANODIZING TERHADAP NILAI KEKERASAN PADA PLAT ALUMINIUM PADUAN AA SERI 2024-T3. Jurnal Angkasa, Volume VIII Nomor 2, 39-48.

[3]. Dong, H. (2010). Surface Engineering of Light alloys
(Aluminium, Magnesium and Titanium Alloys). Padstow, Cornwall, UK: TJ Internasional Limited.

[4]. Kusuma, A. K., Karyasa, I. W., \& Suardana, I. N. (2014). ANODIZING LOGAM ALUMINIUM DENGAN VARIASI BEDA POTENSIAL. Kimia Visvitalis, Volume 2, 138145.

[5]. Sidharta, B. W., Soekrisno, R., \& Iswanto, P. T. (2012, November 3). PENGARUH KONSENTRASI ELEKTROLIT DAN WAKTU ANODISASI TERHADAP KETAHANAN AUS DAN KEKERASAN PADA LAPISAN OKSIDA PADUAN ALUMINIUM ADC12. Periode III, hal. 312-317.

[6]. Araoyinbo, A., Noor, A., Sreekantan, S., \& Aziz, A. (2010). VOLTAGE EFFECT ON ELECTROCHEMICAL ANODIZATION OF ALUMINUM AT AMBIENT TEMPERATURE. International Journal of Mechanical and Materials Engineering (IJMME), Vol. 5 (2010), No. 1, 53-58.

[7]. Dewi, M. (2016). Studi Mikrostruktur dan Sifat Mekanik Aluminium 6061 Melalui Proses Canai DIngin dan Aging. Jurnal Furnace Vol 1 No. 1. 